\title{
Isolation and Characterization of Diazotrophic Rhizobacteria of Oil Palm Roots
}

\author{
Azlin, C.O., Amir, H. G*. and Chan, L. K. \\ School of Biological Sciences, Universiti Sains Malaysia, \\ 11800 Minden, Penang, Malaysia
}

\begin{abstract}
Beneficial rhizobacteria were isolated from two different compartments of oil palm roots; the rhizosphere or rhizoplane and the inner root tissues. The root samples were collected from oil palm plantation at Felda Lepar 9, Temerloh Pahang (Block 17, Square 6) (soil pH 4.30; 10:25 $0.01 \mathrm{M} \mathrm{CaCl}_{2}$ ). Identification of the isolates was conducted by classical biochemical and physiological tests. Acetylene Reduction Assay (ARA) test was also conducted to quantify the ability of the isolates to fix atmospheric $N_{2}$. Twenty-nine strains of rhizobacteria were isolated from root samples and were maintained aerobically on $\mathrm{N}$-free solid media. Seven of the isolates were identified as Gram negative while the rest were Gram positive. The isolates were successfully identified as Paenibacillus durus (formerly $P$. azotofixans), Paenibacillus polymyxa, Azospirillum lipoferum, Herbaspirillum seropedicae and Acetobacter diazotrophicus. The $\mathrm{N}_{2}$ fixation capacities of the isolates ranged from $7.0 \times 10^{-12}$ to $1.0 \times 10^{-8} \mathrm{~mol} \mathrm{C}_{2} \mathrm{H}_{4} / \mathrm{cfu} /$ hour.
\end{abstract}

Keywords: Diazotrophic bacteria, Acetylene Reduction Assay, rhizosphere, rhizoplane, root tissues

\section{INTRODUCTION}

Nitrogen is an essential component of all life form and is a paradox of nature because it cannot be assimilated by plants unless it is reduced to ammonia by diazotrophic microorganisms (Galdagi et al., 2002). Some microorganisms can fix atmospheric nitrogen through a process called Biological Nitrogen Fixation (BNF) and this is an important source of nitrogen for various metabolisms (Flores-Encarnación et al., 1999). It can also supply the fixed $\mathrm{N}_{2}$ to the associated host plants (Gerk et al., 2000; Barbara and Thomas, 1998). The process involves nitrogenase enzymes that reduce gaseous nitrogen into ammonia $\left(\mathrm{NH}_{3}\right)$ and ammonium $\left(\mathrm{NH}_{4}{ }^{+}\right)$(Chatterjee et al., 1997). The process can be analyzed by Acetylene Reduction Assay (ARA) which enables quantification of nitrogenase enzyme activity through reduction of acetylene gas to ethylene. The prospect is bright to apply these $\mathrm{N}_{2}$ fixing isolates effectively as a biofertilizer and bioenhancer for economics crops like oil palm and rice in Malaysia. Application of these biofertilizer and bioenhancer is a new approach to farming and serve as an alternative strategy to avoid excess applications of mineral fertilizer to plants. Thus, the objectives of this experiment were; 1) to isolate beneficial diazotrophic mizobacteria from oil palm roots, 2) to quantify the $\mathbf{N}_{2}$ fixation ability of these isolates by Acetylene Reduction Assay (ARA) and 3 ) to study the nitrogen fixation activity under aerobic or microaerophilic conditions.

\footnotetext{
*Corresponding author
}

\section{MATERIALS AND METHODS}

Isolation of diazotrophic rhizobacteria from oil palm roots

The roots were surface sterilized with $25 \mathrm{~mL} 95 \%$ ethanol for 30 seconds and washed twice with $50 \mathrm{~mL}$ sterile distilled water for 30 seconds. The roots were placed within test tubes containing nitrogen free semisolid malate medium ( $\mathrm{Nfb}$ medium) to isolate inizobacteria from the rhizosphere and rhizoplane through the formation of pellicle after 72 hours of incubation (Roslina et al., 1995). A loopful of pellicle was streaked onto N-free ATCC solid medium (Eskew et al., 1977) and kept under aerobic condition at $30^{\circ} \mathrm{C}$ for 48 hours. The roots were surface sterilized again using $25 \mathrm{~mL} 95 \%$ ethanol for 30 seconds, followed by washing with $50 \mathrm{~mL}$ sterile distilled water for 30 seconds. The roots were crushed with knife and forceps and placed in $20 \mathrm{~mL} \mathrm{Nfb}$ semisolid malate medium to isolate endophytic rhizobacteria. After 72 hours of incubation, a loopful of the pellicle was streaked onto $\mathrm{N}$ free ATCC solid medium and kept under aerobic condition at $30^{\circ} \mathrm{C}$ for 48 hours.

\section{Quantification of nitrogen fixation activity by Acetylene Reduction Assay (ARA)}

The isolates were tested for $N_{2}$ fixation activity using Acetylene Reduction Assay (ARA) for both liquid and semisolid culture conditions. 1) Liquid culture conditions: Liquid culture of each isolate $(10 \mathrm{~mL})$ was placed into an air-tight bottle volume $64 \mathrm{~mL}$, approximately $10 \%$ of the air from each bottle was removed using an air-tight syringe and replaced by purified acetylene gas (99.8\%). The bottles were incubated for 30 minutes for the reduction of acetylene to ethylene by the isolates. At the end of 
incubation, $2 \mathrm{~mL}$ of the gas mixture was withdrawn and transferred into a vacuum tube (Vacutainer ${ }^{\mathrm{TM}} 7 \mathrm{~mL}$ ) (Somasegaran and Hoben, 1985). The ethylene concentration was assayed using G-300 Hitachi gas chromatography fitted with carboxen 1004 micro packed, $2 m \times 1 / 16$ in stainless steel column and flame ionization detector (FID). Nitrogen was used as the carrier gas, had a flow rate of $3.5 \mathrm{kgf} / \mathrm{cm}^{2}$ and the temperature was maintained at $165^{\circ} \mathrm{C}$ (column) and $230^{\circ} \mathrm{C}$ (injector and detector), respectively. The actual concentration of ethylene was determined based on a standard curve of ethylene concentration ( $\mu \mathrm{mol} \mathrm{C}_{2} \mathrm{H}_{4}$ ) and the peak area percentage. The nitrogen fixation activity ( $\mu \mathrm{mol}$ $\mathrm{C}_{2} \mathrm{H}_{4}$ /cfu/hour) was defined from the ethylene concentration recorded $\left(\mu \mathrm{mol} \mathrm{C}_{2} \mathrm{H}_{4}\right.$ ) and the viable cell numbers (cfu) of the isolates tested. 2) Semisolid culture conditions: The ARA test was carried out in an air-tight 30 $\mathrm{mL}$ universal bottle containing $10 \mathrm{~mL} \mathrm{Nfb}$ semisolid malate media, inoculated with the respective isolates. The isolates were incubated in the Nfb semisolid malate media for 72 hours for pellicle formation before the acetylene gas was injected into the head atmosphere of the universal bottles ( $5 \% \mathrm{v} / \mathrm{v})$ followed by gas incubation for 24 hours at $30^{\circ} \mathrm{C}$ (Elbeltagy et al., 2001). At the end of the incubation, $2 \mathrm{~mL}$ of the gas mixture was withdrawn and transferred into a vacuum tube before assaying for ethylene.

\section{Phenotypic characterization of diazotrophic bacteria}

The isolates were identified based on physiological and biochemical characterizations. The tests involved were Gram staining, $\mathrm{KOH}$ test (Arthi et al., 2003), endospore staining, oxidase, catalase, nitrate reductase, urea hydrolysis, Voges-Proskauer, starch hydrolysis, hydrogen sulfide and indole tests (Seldin et al., 1998; Mavingui et al., 1992).

\section{RESULTS AND DISCUSSION}

Twenty-nine strains of rhizobacteria were successfully isolated from three different compartments of oil palm roots grown at Felda Lepar 9, Temerloh Pahang. Fifteen strains have been successfully isolated from thizosphere or rhizoplane of oil palm root and fourteen strains were isolated from inner root tissues (Table 1 and 2). The strains isolated from the inner root tissues were categorized as putative endophytes that form association with their host plants by colonizing the internal tissue (Muthukumurasamy et al., 2002).

The Gram positive isolates that showed positive results for catalase, starch hydrolysis, nitrate reductase but negative for indole and oxidase test could be identified as Paenibacillus macerans and Paenibacillus polymyxa. However, $P$. macerans was different from $P$. polymyxa since the former did not produce acetylmethylcarbinol in the Voges-Proskauer test (Seldin et al., 1983) (Table 2). Isolate E14 was suspected to be $P$. polymyxa capable of fixing nitrogen up to $9.608 \times 10^{-9}\left(\mathrm{~mol} \mathrm{C}_{2} \mathrm{H}_{4} / \mathrm{cfu} / \mathrm{hour}\right.$ (microaerophilic conditions) and $4.442 \times 10^{-9}$ (mol $\mathrm{C}_{2} \mathrm{H}_{4} /$ cfu/hour under aerobic conditions (Table 3 ). The result also showed that isolate $\mathrm{R} 4$ had similar characteristics to Paenibacillus durus as shown earlier by Seldin et al., (1998) which were positive for catalase and Voges-Proskauer test and negative for oxidase and nitrate reductase test. Isolate $\mathrm{R} 4$ could successfully fix $\mathrm{N}_{2}$ under aerobic condition at $1.711 \times 10^{-5}$ (mol $\mathrm{C}_{2} \mathrm{H}_{4} / \mathrm{cfu} /$ hour and $2.161 \times 10^{-9}$ (mol $\mathrm{C}_{2} \mathrm{H}_{4} /$ cfu/hour under microaerophilic condition (Table 3 ).

Results on the biochemical tests of isolates E10 and R2 (Table 1 and 2) showed similar characteristics to type strains of Azospirillum brasilense or Herbaspirillum seropedicae. The isolates were able to form pellicle in $\mathrm{N}$ free semisolid malate medium. Formation of subsurface pellicle in $\mathrm{N}$-free semisolid malate medium was often taken as an evidence that Azospirillum spp. was present (Roslina et al., 1985). Isolate E10 showed similar characteristics with Azospirillum spp. (positive results for methyl red and Voges-Proskauer test) and possibly belonged to $A$. lipoferum capable of fixing $\mathrm{N}_{2}$ under microaerophilic conditions $\left(2.367 \times 10^{-8} \mu \mathrm{mol}\right.$ $\mathrm{C}_{2} \mathrm{H}_{4}$ /cfu/hour). Isolate $\mathrm{R} 2$ was tentatively grouped together with Herbaspirillum seropedicae that could successfully fix $\mathrm{N}_{2}$ in aerobic and microaerophilic conditions at $1.332 \times 10^{-7}$ and $1.757 \times 10^{-10} \mu \mathrm{mol}$ $\mathrm{C}_{2} \mathrm{H}_{4} / \mathrm{cfu} /$ hour, respectively. Earlier findings have shown that Azospirillum could fix $\mathrm{N}_{2}$ under microaerobic conditions and was known to colonize roots while Herbaspirillum was an endophytic diazotroph (Kennedy et al., 2004, Muthukumarasamy et al., 1999). Muthukumarasamy et al., (1999) also reported that Herbaspirillum seropedicae could increase leaf $\mathrm{N}$ content and cane yields significantly. Han and New (1998) have shown that $A$. lipoferum had a higher average nitrogenase activity than $A$. brasilense, both in $\mathrm{Nfb}$ medium and in association with wheat roots with $79.9 \mathrm{nmol} \mathrm{C}_{2} \mathrm{H}_{4} / \mathrm{mg}$ protein/ hour.

Isolates R6 and R12 showed similar characteristics with Acetobacter (Glucona acetobacter) diazotrophicus (Table 1) (negative for Gram reaction, oxidase and starch hydrolysis but positive for catalase and nitrogenase activity), which was isolated earlier by Muthukumarasamy et al. (2002) from sugarcane. Ability of the isolates to form pellicle in $\mathrm{Nfb}$ semisolid malate medium was also recorded together with the ability to fix nitrogen under aerobic and microaerophilic conditions. Formation of acid from D-glucose indicated that the isolates could produce acid from D-glucose, D-mannose, i-inositol, D-mannitol, Darabinose and D-fructose. Isolates R6 and R12 were suspected to be $A$. diazotrophicus capable of fixing $N_{2}$ at $4.8 \times 10^{-11} \mu \mathrm{mol} \mathrm{C}_{2} \mathrm{H}_{4} / \mathrm{cfu} / \mathrm{hour}$ and $4.012 \times 10^{-7} \mu \mathrm{mol}$ $\mathrm{C}_{2} \mathrm{H}_{4} /$ cfu/hour in aerobic condition and $6.598 \times 10^{-12} \mu \mathrm{mol}$ $\mathrm{C}_{2} \mathrm{H}_{4}$ /cfu/hour and $1.187 \times 10^{-8} \mu \mathrm{mol} \mathrm{C}_{2} \mathrm{H}_{4} / \mathrm{cfu} /$ hour in microaerophilic condition, respectively. Acetobacter is well-known as an aerotolerant diazotroph in which oxygen is instrumental for the generation of large quantities of ATP required for nitrogen fixation (Flores-Encarnación et al., 1999) and has been proven to contribute up to $60-80$ $\%$ of sugarcane plant $\mathbf{N}$ requirement (equivalent to over $200 \mathrm{~kg} / \mathrm{N} / \mathrm{ha} / \mathrm{yr}$ ) from $\mathrm{N}_{2}$ fixation process (Kennedy et al., 2004). 
Mal. J. Microbiol. Vol 1 (1) 2005, pp. 31-35

Table1: Physiological and biochemical characterizations of the isolates from thizosphere of oil palm roots

\begin{tabular}{|c|c|c|c|c|c|c|c|c|c|c|c|c|c|c|c|}
\hline \multirow[t]{2}{*}{ TEST } & \multicolumn{15}{|c|}{ Isolates } \\
\hline & R1 & $\mathrm{R} 2$ & R3 & R4 & R5 & R6 & $\overline{\mathrm{R} 7}$ & R8 & R9 & R10 & R11 & R12 & R13 & R14 & R15 \\
\hline Gram Staining & - & - & + & + & - & - & + & + & + & + & + & - & + & + & + \\
\hline Endospore stain & + & - & + & + & - & - & - & + & + & + & - & - & - & - & - \\
\hline $\mathrm{KOH}$ test & + & + & - & - & + & + & - & - & - & - & - & + & - & - & - \\
\hline $\mathrm{N}$-free medium & + & + & + & + & + & + & + & + & + & + & + & + & + & + & + \\
\hline Oxidase & + & + & + & + & + & - & - & + & + & + & + & - & + & + & + \\
\hline Methyl Red & + & + & + & + & + & + & + & + & + & + & - & + & + & + & - \\
\hline Voges-Proskauer & + & + & + & - & + & + & - & + & + & - & + & + & + & + & + \\
\hline Nitrate Reductase & + & + & + & + & + & + & + & + & + & + & - & + & + & + & - \\
\hline Starch Hydrolysis & - & + & - & + & - & - & + & - & + & + & - & - & + & - & + \\
\hline Catalase & + & - & - & + & + & + & + & + & + & - & + & + & + & + & + \\
\hline Indole & - & - & - & - & - & - & - & - & - & - & - & - & - & - & - \\
\hline Urea test & + & + & + & - & + & - & - & - & + & + & - & + & - & + & - \\
\hline Pellicle formation & + & + & + & + & + & + & + & + & + & + & + & + & + & + & + \\
\hline
\end{tabular}

Table 2: Physiological and biochemical characterizations of the isolates from inner root tissues of oil palm

\begin{tabular}{|c|c|c|c|c|c|c|c|c|c|c|c|c|c|c|}
\hline \multirow[t]{2}{*}{ TEST } & \multicolumn{14}{|c|}{ Isolates } \\
\hline & E1 & E2 & E3 & $\mathrm{E4}$ & E5 & E6 & E7 & $\mathrm{E8}$ & E9 & $\mathrm{E} 10$ & E11 & $\mathrm{E} 12$ & E13 & E14 \\
\hline Gram Staining & + & + & + & + & + & + & + & + & - & - & + & + & + & + \\
\hline Endospore stain & - & - & + & - & - & - & - & - & + & - & - & + & + & + \\
\hline $\mathrm{KOH}$ test & - & - & - & - & - & - & - & - & + & + & - & - & - & - \\
\hline $\mathrm{N}$-free medium & + & + & + & + & + & + & + & + & + & + & + & + & + & + \\
\hline Oxidase & - & + & + & + & + & + & + & + & - & + & - & + & - & - \\
\hline Methyl Red & - & + & + & + & + & + & + & + & + & + & - & - & - & + \\
\hline Voges-Proskauer & + & + & + & + & + & + & + & + & + & + & + & + & + & + \\
\hline Nitrate Reductase & + & + & + & + & + & + & - & + & + & - & + & - & + & + \\
\hline Starch Hydrolysis & - & + & - & + & + & + & + & - & - & + & - & - & - & + \\
\hline Catalase & + & + & + & + & + & + & + & + & + & - & + & + & + & + \\
\hline Indole & - & - & - & - & - & - & - & - & - & - & - & - & - & - \\
\hline Urea test & + & + & + & - & + & - & - & + & + & + & - & - & - & - \\
\hline Pellicle formation & + & + & + & + & + & + & + & + & + & + & + & + & + & + \\
\hline
\end{tabular}


Table 3: Nitrogenase activities ( $\mu \mathrm{mol} \mathrm{C}_{2} \mathrm{H}_{4} / \mathrm{cfu} / \mathrm{hour}$ ) by isolates from the rhizosphere and inner root tissues of oil palm

\begin{tabular}{|c|c|c|c|c|}
\hline $\begin{array}{c}\text { Root } \\
\text { Compartments } \\
\end{array}$ & Isolates & $\begin{array}{l}\text { Identified } \\
\text { Strains }\end{array}$ & $\begin{array}{l}\text { umol } \mathrm{C}_{2} \mathrm{H}_{4} / \text { cfu/hour } \\
\text { (Aerobic conditions) }\end{array}$ & $\begin{array}{c}\mu \mathrm{mol} \mathrm{C}_{2} \mathrm{H}_{4} / \mathrm{cfu} / \mathrm{hour} \\
\text { (Microaerophilic conditions) }\end{array}$ \\
\hline Rhizosphere & $\begin{array}{l}\text { R1 } \\
\text { R2 } \\
\text { R3 } \\
\text { R4 } \\
\text { R5 } \\
\text { R6 } \\
\text { R7 } \\
\text { R8 } \\
\text { R9 } \\
\text { R10 } \\
\text { R11 } \\
\text { R12 } \\
\text { R13 } \\
\text { R14 } \\
\text { R15 }\end{array}$ & $\begin{array}{l}\text { Unidentified } \\
\text { H. seropedicae } \\
\text { Unidentified } \\
P . \text { durus } \\
\text { Unidentified } \\
\text { A. diazotrophicus } \\
\text { Unidentified } \\
\text { Unidentified } \\
\text { Unidentified } \\
\text { Unidentified } \\
\text { Unidentified } \\
\text { A. diazotrophicus } \\
\text { Unidentified } \\
\text { Unidentified } \\
\text { Unidentified }\end{array}$ & $\begin{array}{c}2.755 \times 10^{-8} \\
1.332 \times 10^{-7} \\
6.65 \times 10^{-8} \\
1.711 \times 10^{-5} \\
- \\
4.8 \times 10^{-11} \\
- \\
3.911 \times 10^{-10} \\
- \\
- \\
2.429 \times 10^{-7} \\
4.012 \times 10^{-7} \\
- \\
- \\
-\end{array}$ & $\begin{array}{c}1.187 \times 10^{-8} \\
1.757 \times 10^{-10} \\
1.652 \times 10^{-8} \\
2.161 \times 10^{-9} \\
1.176 \times 10^{-11} \\
6.598 \times 10^{-12} \\
3.884 \times 10^{-10} \\
2.761 \times 10^{-10} \\
- \\
- \\
2.418 \times 10^{-7} \\
1.187 \times 10^{-8} \\
5.638 \times 10^{-11} \\
4.148 \times 10^{-11} \\
2.126 \times 10^{-11}\end{array}$ \\
\hline Root Tissues & $\begin{array}{l}\text { E1 } \\
\text { E2 } \\
\text { E3 } \\
\text { E4 } \\
\text { E5 } \\
\text { E6 } \\
\text { E7 } \\
\text { E8 } \\
\text { E9 } \\
\text { E10 } \\
\text { E11 } \\
\text { E12 } \\
\text { E13 } \\
\text { E14 }\end{array}$ & $\begin{array}{l}\text { Unidentified } \\
\text { Unidentified } \\
\text { Unidentified } \\
\text { Unidentified } \\
\text { Unidentified } \\
\text { Unidentified } \\
\text { Unidentified } \\
\text { Unidentified } \\
\text { Unidentified } \\
\text { A. lipoferum } \\
\text { Unidentified } \\
\text { Unidentified } \\
\text { Unidentified } \\
\text { P. polymyxa }\end{array}$ & $\begin{array}{c}- \\
- \\
- \\
- \\
- \\
- \\
5.354 \times 10^{-10} \\
- \\
7.865 \times 10^{-10} \\
- \\
- \\
- \\
3.286 \times 10^{-10} \\
4.442 \times 10^{-9}\end{array}$ & $\begin{array}{l}6.200 \times 10^{-8} \\
3.080 \times 10^{-8} \\
3.409 \times 10^{-8} \\
8.592 \times 10^{-7} \\
6.994 \times 10^{-9} \\
4.919 \times 10^{-9} \\
3.165 \times 10^{-8} \\
1.228 \times 10^{-7} \\
7.776 \times 10^{-9} \\
2.367 \times 10^{-8} \\
4.023 \times 10^{-8} \\
2.965 \times 10^{-8} \\
2.979 \times 10^{-9} \\
9.608 \times 10^{-9}\end{array}$ \\
\hline
\end{tabular}

\section{CONCLUSION}

The experiment had successfully isolated and identified the diazotrophic rhizobacteria from the rhizosphere (Herbaspirillum seropedicae, Paenibacillus durus and Acetobacter diazotrophicus) and from the inner root tissues (Azospirillum lipoferum and Paenibacillus polymyxa) of oil palm. The rhizopheric and endophytic isolates could fix $\mathrm{N}_{2}$ under aerobic and microaerophilic conditions as determined by Acetylene Reduction Assay (ARA).

\section{ACKNOWLEDGEMENTS}

The authors are indebted to School of Biological Sciences, USM, Penang, Yayasan Felda for the research funding and Felda Lepar 9, Temerloh, Pahang.

\section{REFERENCES}

Arthi, K., Appalaraju, B. and Parvathi, S. (2003). Vancomycin sensitivity and $\mathrm{KOH}$ string test as an alternative to Gram staining of bacteria. Indian Journal of Medical Microbiology. 21(2):121-123.

Barbara, R. H. and Thomas, H. (1998). Life in grasses: Diazotrophic endophytes. Trends in Microbiology. 6(4):139-144.
Chatterjee, R., Allen, R. M., Ludden, P. W. and Shah, V. K. (1997). In vitro synthesis of the iron-molybdenum cofactor and maturation of the nif-encoded apodinitrogenase. Journal of Biological Chemistry. 272(34):21604-21608.

Elbeltagy, A., Nishioka, K., Sato, T., Suzuki, H., Ye, B., Hamada, T., Isawa, T., Mitsui, H. and Minamisawa, K. (2001). Endophytic colonization and in planta nitrogen fixation by a Herbaspirillum sp. isolated from wild rice species. Applied and Environmental Microbiology. 67(11):5285-5293.

Eskew D. L., Focht, D. D. and Ting. I. P. (1977). Nitrogen fixation, denitrification and pleomorphic growth in a highly pigmented Spirillum lipoferum. Applied and Environmental Microbiology. 34:582-585.

Flores-Encarnación, M., Conteras-Zentella, M., SotoUrzua, L., Arguilar, G. R., Baca, B. E. and Escamilla, J. E. (1999). The respiratory system and diazotrophic activity of Acetobacter diazotrophicus PAL5. Journal of Bacteriology. 181(22):6987-6995.

Galdagi, R., Krishnaraj, P. U., Kulkarni, J. H. and Tangmin, S. A. (2002). Biodiversity of Azospirillum in ornamental rhizosphere soils of Karnataka. Proceedings of the $17^{\text {th }}$ WCSS Symposium, Thailand. p. 537 (1-9).

Gerk, L. P., Gilchrist, K. and Kennedy, I. R. (2000). Mutants with enhanced nitrogenase activity in 
Azospirillum brasilense-wheat associations. Applied and Environmental Microbiology. 66(5):2175-2184.

Han, S. O. and New, P. B. (1998). Variation in nitrogen fixing ability among natural isolates of Azospirillum. Microbial Ecology. 36:193-201

Kennedy, I. R., Choudhury, A. T. M. A. and Kecskes, M. L. (2004). Non-symbiotic bacterial diazotrophs in crop-farming systems: can their potential for plant growth promotion be better exploited? Soil Biology and Biochemistry. p. 1-16

Mavingui, P., Laguerre, G., Berge, 0 . and Heulin, T. (1992). Genetic and phenotypic diversity of Bacillus polymyxa in soil and in the wheat rhizosphere. Applied and Environmental Microbiology. 58(6):18941903.

Muthukumarasamy, R., Revathi, G. and Lakshminarasimhan, C. (1999). Influence of $N$ fertilization on the isolation of Acetobacter diazotrophicus and Herbaspirillum spp. from Indian sugarcane varieties. Biology Fertility Soils. 29:157164.

Muthukumarasamy, R., Revathi, G., Seshadri, S. and Lakshminarasimhan, C. (2002). Gluconacetobacter diazotrophicus (syn. Acetobacter diazotrophicus), a promosing diazotrophic endophyte in tropics. Current Science, 83(2):137-145.

Roslina, A.W. and Zulkifli, H. S. (1995). Isolation of Azospirillum spp. from oil palm roots. Proceedings of the $18^{\text {th }}$ Microbiology. Malaysian Society for Microbiology, Malaysia. p 1-9.

Seldin, L., Rosado, A. S., Da Cruz, D. W., Nobrega, A., Van Elsas, J. D. and Paiva, E. (1998). Comparison of Paenibacillus azotofixans strains isolated from rhizoplane, rhizosphere and non-root-associated soil from maize planted in two different Brazillian soils. Applied and Environmental Microbiology. p 38603868.

Seldin, L., Van Elsas, J. D. and Penido, E. G. C. (1983). Bacillus nitrogen fixers from Brazillian soils. Plant Soil. 70:243-255.

Somasegaran, P. and Hoben, H. J. (1985). Methods in legume-Rhizobium technology. University of Hawaii NifTAL project MICREN. United State Agency for International Development (USAID). p. 320-327. 